\title{
Exploitation of methane in the hydrate by use of carbon dioxide in the presence of sodium chloride
}

\author{
Li Zunzhao, Guo Xuqiang*, Yang Lanying and Ma Xiaona \\ State Key Laboratory of Heavy Oil Processing, China University of Petroleum, Beijing 102249, China
}

\begin{abstract}
The replacement process of $\mathrm{CH}_{4}$ from $\mathrm{CH}_{4}$ hydrate formed in $\mathrm{NaCl}$ solution by using pressurized $\mathrm{CO}_{2}$ was investigated with a self-designed device at temperatures of 271.05, 273.15 and $275.05 \mathrm{~K}$ and a constant pressure of $3.30 \mathrm{MPa}$. The mass fraction of the $\mathrm{NaCl}$ solution was either 0.5 $\mathrm{wt} \%$ or $1.0 \mathrm{wt} \%$. The effects of temperature and concentration of $\mathrm{NaCl}$ solution on the replacement process were investigated. Experimental results showed that high temperature was favorable to the replacement reaction but high $\mathrm{NaCl}$ concentration had a negative effect on the replacement process. Based on the experimental data, kinetic models of $\mathrm{CH}_{4}$ hydrate decomposition and $\mathrm{CO}_{2}$ hydrate formation in $\mathrm{NaCl}$ solution were established. The calculated activation energies suggested that both $\mathrm{CH}_{4}$ hydrate decomposition and $\mathrm{CO}_{2}$ hydrate formation are dominated by diffusion in the hydrate phase.
\end{abstract}

Key words: $\mathrm{CO}_{2}$ hydrate, $\mathrm{CH}_{4}$ hydrate, guest molecule replacement, kinetic model

\section{Introduction}

$\mathrm{CH}_{4}$ hydrates are found naturally in regions of permafrost and beneath the sea in outer continental margins. The total amount of methane in $\mathrm{CH}_{4}$ hydrates worldwide is estimated at $0.9 \times 10^{9}-1.02 \times 10^{10}$ tons of oil equivalent (Makogon et al, 2007).

There are three methods available for $\mathrm{CH}_{4}$ hydrate recovery including thermal treatment, depressurization and inhibitor addition (Sloan, 1998). All these methods are aimed at promoting $\mathrm{CH}_{4}$ hydrate decomposition by external stimulation. There are some shortcomings in using the above methods for $\mathrm{CH}_{4}$ hydrate exploitation. For example, the problem with the thermal treatment is the heat lost to reservoir rock and water. For the depressurization method, the decomposition processes for $\mathrm{CH}_{4}$ recovery could lead to weakening the ocean floor (Lee and Holder, 2001). Adding inhibitor into the gas hydrates reservoir would pollute the sea environment.

Another method proposed for gas hydrate exploitation is the injection of $\mathrm{CO}_{2}$. The idea of exchanging $\mathrm{CO}_{2}$ for $\mathrm{CH}_{4}$ in gas hydrates was first advanced by Ohgaki et al (1996). With this method the recovery of natural gas from a gas hydrate is combined with $\mathrm{CO}_{2}$ sequestration. It offers two advantages: reducing $\mathrm{CO}_{2}$ emissions into atmosphere and assisting gas hydrate exploitation, thereby helping overcome the economic impediments of $\mathrm{CO}_{2}$ sequestration and $\mathrm{CH}_{4}$ hydrate dissociation. Due to the consumption of fossil fuels, the world $\mathrm{CO}_{2}$ emissions are expected to increase from 24 billion metric tons in 2001 to 39 billion metric tons in 2025 (Goel, 2006).

*Corresponding author. email: guoxq@cup.edu.cn Received December 31, 2008
$\mathrm{CO}_{2}$ sequestration has become an urgent problem deserving more attention.

The phase equilibrium of the $\mathrm{CO}_{2}-\mathrm{CH}_{4}$ binary system forming hydrates was investigated by Adisasmito et al (1991) and Ohgaki et al (1996). Experiment results show that the formation pressure of $\mathrm{CO}_{2}$ hydrate is lower than that of $\mathrm{CH}_{4}$ hydrate. Seo et al (2001) determined the two-phase equilibria of vapor and hydrate at the three different pressures 20, 26 and 35 bar. They reported that under lower pressure, the empty cavities of the hydrates are preferentially occupied by $\mathrm{CO}_{2}$ rather than $\mathrm{CH}_{4}$ and the replacement process may have good selectivity for $\mathrm{CO}_{2}$. Another mechanism for replacement process is that the exothermic heat of $\mathrm{CO}_{2}$ hydrate formation might induce the decomposition of $\mathrm{CH}_{4}$ hydrate. This mechanism based on the fact that the exothermic heat of $\mathrm{CO}_{2}$ hydrate formation is higher than that required for $\mathrm{CH}_{4}$ hydrate decomposition.

Several researchers have investigated the replacement process for $\mathrm{CH}_{4}$ recovery from $\mathrm{CH}_{4}$ hydrate using pressurized $\mathrm{CO}_{2}$ on a laboratory scale. Ota et al (2005a) conducted a $\mathrm{CO}_{2}$ replacement process of $\mathrm{CH}_{4}$ gas from $\mathrm{CH}_{4}$ hydrate at a temperature range of $271.05-275.05 \mathrm{~K}$ and a pressure of 3.10-3.34 MPa. Jadhawar et al (2005) conducted replacement experiments in porous medium at laboratory scale and the results obtained indicated that the $\mathrm{CH}_{4}$ recovery rate in porous medium was higher than that in bulk conditions obtained by Hirohama et al (1996).

The previous work concentrated on the replacement process with methane hydrates formed in pure water. Experiments of methane recovery from methane hydrates formed in $\mathrm{NaCl}$ solution have rarely been reported so far. As we all know, the natural gas hydrates stored in the seabed were formed in sea water. Although a salt-removing 
effect exists in the hydrate formation process, some $\mathrm{NaCl}$ is still attached to the hydrates and the porous media. So investigation of the kinetic process and the effect of $\mathrm{NaCl}$ on the replacement process are necessary for consideration of any future industrial production of methane from methane hydrates using $\mathrm{CO}_{2}$.

For the first time, we conducted a series of $\mathrm{CH}_{4}$ replacement experiments of $\mathrm{CH}_{4}$ hydrate formed in $\mathrm{NaCl}$ solution by using pressurized $\mathrm{CO}_{2}$ at laboratory scale at isothermal conditions $(271.05 \mathrm{~K}, 273.15 \mathrm{~K}$ and $275.05 \mathrm{~K}$ ) under pressures just above the $\mathrm{CH}_{4}$ hydrate dissociation pressure (3.30 MPa). Based on the experimental data, a kinetic model was developed for $\mathrm{CH}_{4}$ hydrate decomposition and $\mathrm{CO}_{2}$ hydrate formation. Our objective was to investigate the effect of different factors on $\mathrm{CH}_{4}$ replacement from $\mathrm{CH}_{4}$ hydrates and provide a guide for possible future industrial exploitation of methane hydrates with $\mathrm{CO}_{2}$ sequestration.

\section{Experimental}

\subsection{Experimental apparatus}

Fig. 1 is the schematic diagram of the experimental apparatus which consists of four major sections: an equilibrium cell equipped with a magnetic agitator, a sample supply system, a pressure-temperature measurement system and a composition analyzing system.

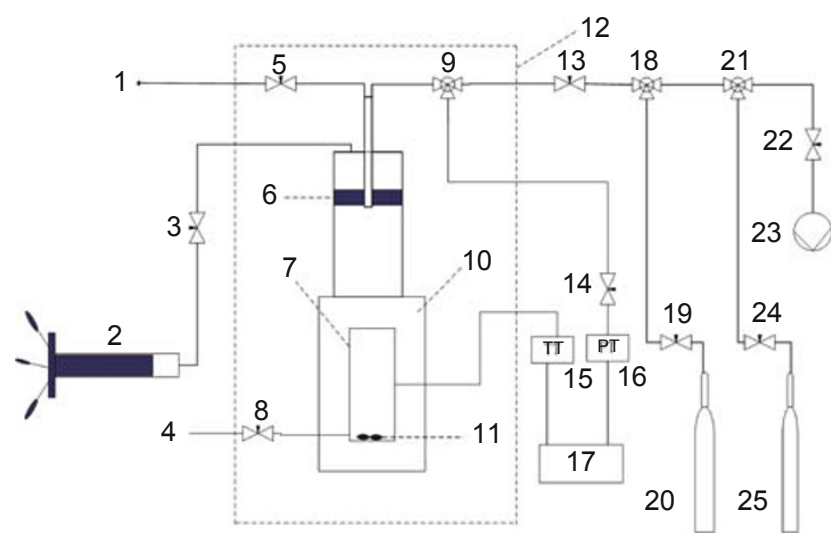

Fig. 1 Schematic diagram of the experimental apparatus

1-sample connection; 2-pressure pump; 3, 5, 8, 9, 13, 14, 17, 18, 19, 21, 22, 24-valve; 4-inlet/outlet for liquid; 6-piston; 7-glass window; 10-equilibrium cell; 11-magnetic stirrer; 12-air bath; 15-temperature sensor; 16-pressure sensor; 17-data acquisition system; $20-\mathrm{CH}_{4}$ gas cylinder; 23-vacuum pump; 25- $\mathrm{CO}_{2}$ gas cylinder

Equilibrium cell The equilibrium cell, with an internal volume of $420 \mathrm{~cm}^{3}$, consists of a visual cell and a blind cell whose volume can be changed by a piston in it using a pressure pump. The pressure of the equilibrium cell can be maintained by changing the volume of the blind cell. The equilibrium cell was made of stainless steel, which allowed a maximum pressure of $20 \mathrm{MPa}$, and had a pair of glass windows on opposite side for observing gas hydrate and phase behavior. A magnetic stirrer was used to agitate fluids in the cell. Water or solution was fed into the cell by a plunger pump.

Sample supply system The gas-sample charging system consists of $\mathrm{CH}_{4}$ and $\mathrm{CO}_{2}$ gas cylinders and a vacuum pump which was used to evacuate the cell.

Pressure-temperature measurement system The equilibrium pressure was measured by using an online pressure sensor (JYB-KH) with an accuracy of about $0.01 \mathrm{MPa}$. The temperature was controlled by a programmed thermo-controller (CWYF-1) and measured with a temperature sensor (PT 100) with an accuracy of $\pm 0.1 \mathrm{~K}$.

Analyzing system for gas composition For a mixed hydrate system, the composition of the gas-phase in equilibrium at a given temperature and pressure was measured directly by a gas chromatograph (HP6890). As the amount of water in the gas phase is negligibly small in the present experimental conditions, the gas-phase composition was only analyzed for $\mathrm{CO}_{2}$ and $\mathrm{CH}_{4}$. The composition was determined by comparing the peak area ratio of the unknown sample with that of a known standard sample of similar concentration.

Materials $\mathrm{CH}_{4}$ and $\mathrm{CO}_{2}$ gases used in this study were purchased from AP Beifen Gases Industry Co., Ltd, Beijing, China, with a certified purity of 99.99 vol\%. $\mathrm{NaCl}$ was purchased from Beijing Shuanghuan Chemical Reagent Factory, China, with a certified purity $99.5 \mathrm{wt} \%$. Distilled water was produced with a water distillation apparatus (SZ-93, Shanghai Yarong Biochemistry Instrument Factory, China).

\subsection{Experimental procedures}

Formation of $\mathrm{CH}_{4}$ hydrates $\mathrm{NaCl}$ solution $(0.5 \mathrm{wt} \%$ or $1.0 \mathrm{wt} \%$ ) was added into the equilibrium cell at $273.2 \mathrm{~K}$. $\mathrm{CH}_{4}$ gas was introduced into the cell from the $\mathrm{CH}_{4}$ cylinder. The cell was then pressurized up to $8.0 \mathrm{MPa}$, which is much higher than the three-phase equilibrium pressure of $\mathrm{CH}_{4}$ hydrate at the operating temperature which was listed in Table 2. Agitation in the cell was started to promote the $\mathrm{CH}_{4}$ hydrate forming. The gas phase pressure $(8.0 \mathrm{MPa})$ was kept constant during the $\mathrm{CH}_{4}$ hydrate formation.

Replacement of $\mathrm{CH}_{4}$ from $\mathrm{CH}_{4}$ hydrate using pressurized $\mathrm{CO}_{2}$ First, the piston in the blind cell was moved to its bottom to make the volume of the equilibrium cell minimum. The temperature of the air bath was set to $267.8 \mathrm{~K}$, at which $\mathrm{CH}_{4}$ hydrate is very stable (Stern et al, 2001). Then in order to purge the cell by $\mathrm{CO}_{2}$ gas, the $\mathrm{CH}_{4}$ gas in the cell was released gradually to $1.60 \mathrm{MPa}$ which was slightly higher than the equilibrium pressure of $\mathrm{CH}_{4}$ hydrate at $267.8 \mathrm{~K}$. Second, $\mathrm{CO}_{2}$ gas was introduced into the cell gradually to 3.00 $\mathrm{MPa}$ which was slightly lower than the saturation pressure of $\mathrm{CO}_{2}$ at $267.8 \mathrm{~K}$ and at the same time the volume of the blind cell was expanded to the maximum value $(200 \mathrm{~mL})$ by moving the piston to the top of the blind cell. The above two steps were repeated for three times to make sure that only a little $\mathrm{CH}_{4}$ gas (less than $0.075 \mathrm{~mol} \%$ ) remained in the gas phase. The temperature of the cell was gradually raised to the desired operating value (Table 1) and the pressure was also increased to the desired value (Table 1) by driving the piston in the blind cell. A small amount of gas phase was sampled with an injector for analysis of the initial composition of the gas phase by gas chromatography. The time for temperature 
rising was usually less than 60 minutes. The gas phase was sampled and analyzed as a function of time. Finally, after 100-150 hours passed, the hydrate mixture was decomposed by increasing the cell's temperature to $298.15 \mathrm{~K}$ and the gas composition was analyzed.

Table 1 lists the experimental conditions. The total amount $\left(n{ }_{\text {Total }}^{\text {end }}\right)$ of the gas mixture in the gas phase was determined with PT equation of state (Patel and Teja, 1982) by using the experimental temperature, and the gas phase volume and the gas composition were measured after the $\mathrm{CH}_{4}$ and $\mathrm{CO}_{2}$ hydrates mixture was decomposed. The initial amount $\left(n_{\mathrm{CH}_{4}, \mathrm{H}}^{i}\right)$ of $\mathrm{CH}_{4}$ trapped in the $\mathrm{CH}_{4}$ hydrate phase was determined by Eq. 1 . The initial amount $\left(n_{\mathrm{CH}_{4}, \mathrm{H}}^{i}\right)$ of $\mathrm{CO}_{2}$ and the total amount $\left(n_{\text {Total }}^{i}\right)$ of the gas mixture were also calculated with PT equation of state by using the experimental temperature, the gas phase volume and the gas composition which were measured at the beginning of the replacement reaction. The results showed that not all the $\mathrm{H}_{2} \mathrm{O}$ molecules can react with $\mathrm{CH}_{4}$ molecules to form $\mathrm{CH}_{4}$ hydrate and the average gas storage of $\mathrm{CH}_{4}$ hydrate is about $45.2 \mathrm{Sm}^{3}$ of methane per $\mathrm{m}^{3}$ of pure hydrate.

$$
\begin{aligned}
& n_{\mathrm{CH}_{4}, \mathrm{H}}^{i}=n_{\text {Total }}^{\text {end }} \times n_{\mathrm{CH}_{4}} \% \\
& n_{\mathrm{CO}_{2}, \mathrm{G}}^{i}=n_{\text {Total }}^{i} \times n_{\mathrm{CO}_{2}} \%
\end{aligned}
$$

Where, $n_{\mathrm{CH}_{4}} \%$ and $n_{\mathrm{CO}_{2}} \%$ mean the mole fraction of $\mathrm{CH}_{4}$ and $\mathrm{CO}_{2}$, respectively. The volume of gas phase at the beginning of the replacement reaction, which was used to calculate the $n$ Total in Eq. 2, was calculated from the volume of equilibrium cell, the dilatation of structure I hydrate, and the initial volume of the liquid solution or water.

Table 1 Experimental conditions

\begin{tabular}{ccccccc}
\hline$T, \mathrm{~K}$ & $P, \mathrm{MPa}$ & $\begin{array}{c}\text { Mass of } \\
\text { NaCl solution, } \mathrm{g}\end{array}$ & $\begin{array}{c}\text { Molality of } \\
\mathrm{NaCl}, \mathrm{wt} \%\end{array}$ & $n_{\mathrm{CH}_{\mathrm{H}} \mathrm{H}}^{i}, \mathrm{~mol}$ & $n_{\mathrm{CH}_{3} \mathrm{G}}^{i}, \mathrm{~mol}$ & $n_{\mathrm{CH}_{2} \mathrm{G}}^{i} n_{\mathrm{CH}_{3}, \mathrm{H}}^{i}$ \\
\hline 271.05 & 3.30 & 140.0 & 1.0 & 0.2989 & 0.4840 & 2.866 \\
273.15 & 3.30 & 140.0 & 1.0 & 0.2963 & 0.5061 & 1.708 \\
275.05 & 3.30 & 140.0 & 1.0 & 0.2371 & 0.4878 & 2.057 \\
275.05 & 3.30 & 140.0 & 0.5 & 0.2982 & 0.4933 & 1.654 \\
\hline
\end{tabular}

Table 2 shows the equilibrium pressures of $\mathrm{CH}_{4}$ hydrate and $\mathrm{CO}_{2}$ hydrate at different conditions which were calculated with the Chen-Guo hydrate model(Chen and Guo, 1998).

Table 2 Equilibrium pressures of methane hydrate and $\mathrm{CO}_{2}$ hydrate at different conditions

\begin{tabular}{ccccc}
\hline$T, \mathrm{~K}$ & $P, \mathrm{MPa}$ & $\begin{array}{c}\text { Molality of } \\
\text { solute, } \mathrm{wt} \%\end{array}$ & $\begin{array}{c}\text { Equilibrium pressure of } \\
\mathrm{CH}_{4} \text { hydrate, } \mathrm{MPa}\end{array}$ & $\begin{array}{c}\text { Equilibrium pressure of } \\
\mathrm{CO}_{2} \text { hydrate, } \mathrm{MPa}\end{array}$ \\
\hline 271.05 & 3.30 & 1.0 & 2.38 & 1.02 \\
273.15 & 3.30 & 1.0 & 2.70 & 1.30 \\
275.05 & 3.30 & 1.0 & 3.27 & 1.68 \\
275.05 & 3.30 & 0.5 & 3.18 & 1.57 \\
\hline
\end{tabular}

During the replacement process, the moles of each components in the gas phase and in the hydrate phase were calculated with the following equations.

$$
\begin{aligned}
& n_{\mathrm{CH}_{4}, \mathrm{G}}=n_{\mathrm{Total}, \mathrm{G}} \times n_{\mathrm{CH}_{4}} \% \\
& n_{\mathrm{CO}_{2}, \mathrm{G}}=n_{\mathrm{Total}, \mathrm{G}} \times n_{\mathrm{CO}_{2}} \% \\
& n_{\mathrm{CH}_{4}, \mathrm{H}}=n_{\mathrm{CH}_{4}, \mathrm{H}}^{i}-n_{\mathrm{CH}_{4}, \mathrm{G}} \\
& n_{\mathrm{CO}_{2}, \mathrm{H}}=n_{\mathrm{CO}_{2}, \mathrm{G}}^{i}-n_{\mathrm{CO}_{2}, \mathrm{G}}
\end{aligned}
$$

Where $n_{\text {Total, G }}$ refers the total moles of $\mathrm{CH}_{4}$ and $\mathrm{CO}_{2}$ in gas phase. While $n_{\mathrm{CH}_{4}, \mathrm{H}}$ and $n_{\mathrm{co}_{2}}$ mean the moles of $\mathrm{CH}_{4}$ and $\mathrm{CO}_{2}$ respectively trapped in the hydrate phase.

\section{Results and discussion}

Fig. 2 and Fig. 3 show the relationship of $\mathrm{CH}_{4}$ amount $\left(n_{\mathrm{CH}_{4}, \mathrm{G}}\right)$ from $\mathrm{CH}_{4}$ hydrate decomposition, and $\mathrm{CO}_{2}$ amount $\left(n_{\mathrm{Co}_{2}, \mathrm{H}}\right)$ trapped in $\mathrm{CO}_{2}$ hydrates, with time, respectively, at different temperatures. The amount of $\mathrm{CH}_{4}$ recovered from $\mathrm{CH}_{4}$ hydrate and that of $\mathrm{CO}_{2}$ formed to $\mathrm{CO}_{2}$ hydrate increased with time. The effect of temperature on the replacement efficiency is significant. Increasing the temperature can enhance the replacement rate. 


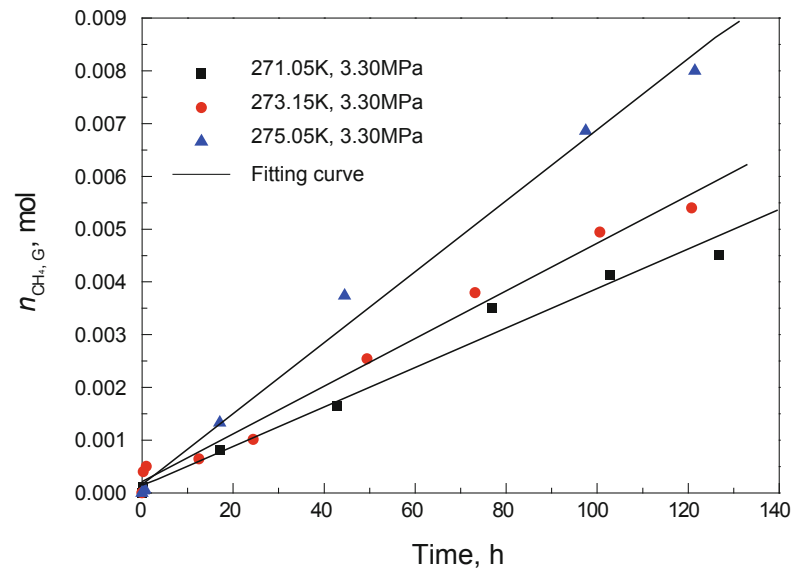

Fig. 2 Relationship of the $\mathrm{CH}_{4}$ amount $\left(n_{\mathrm{CH}_{4}, \mathrm{G}}\right)$ from $\mathrm{CH}_{4}$ hydrate decomposition with time at different temperatures

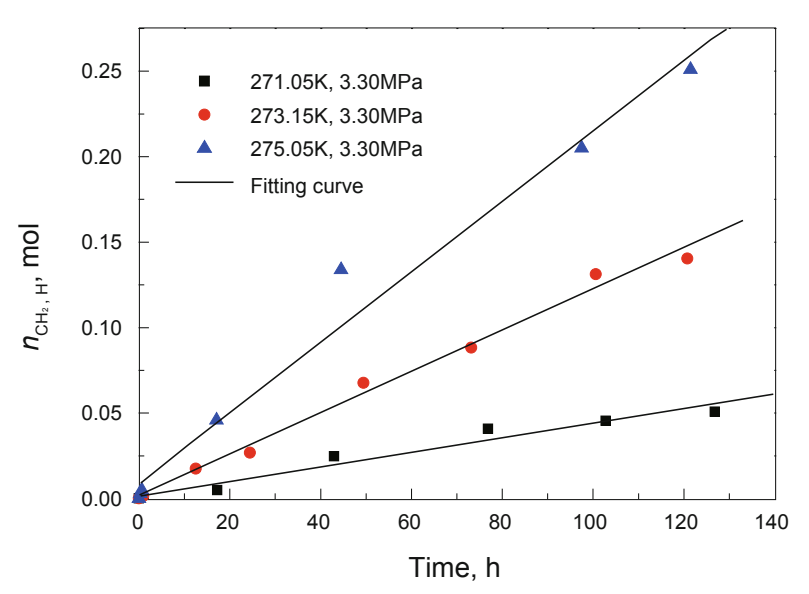

Fig. 3 Relationship of the $\mathrm{CO}_{2}$ amount $\left(n_{\mathrm{CO}_{2}, \mathrm{H}}\right)$ trapped in $\mathrm{CO}_{2}$ hydrate with time

Fig. 4 and Fig. 5 show the effect of $\mathrm{NaCl}$ concentration on the replacement process. It can be seen that $\mathrm{NaCl}$ concentration did not influence the replacement rate nearly as much as the temperature did. And that at the same temperature, the lower the $\mathrm{NaCl}$ concentration, the higher the replacement rate, indicating that $\mathrm{NaCl}$ concentration is an influencing factor for the replacement process.

Fig. 4 and Fig. 5 also show that the $\mathrm{CH}_{4}$ released from $\mathrm{CH}_{4}$ hydrate decomposition by replacement with $\mathrm{CO}_{2}$ is not equal to the amount of $\mathrm{CO}_{2}$ trapped in the hydrate phase, the former is larger than the later. Table 1 shows that the gas storage of $\mathrm{CH}_{4}$ hydrate did not reach the ideal storage (150-180 $\mathrm{Sm}^{3}$ of methane per $\mathrm{m}^{3}$ of pure hydrate) (Hao et al, 2008) and some absorbed water existed in the $\mathrm{CH}_{4}$ hydrate phase. One reason for the difference in $\mathrm{CH}_{4}$ and $\mathrm{CO}_{2}$ amounts might be that some $\mathrm{CO}_{2}$ molecules formed hydrate with the absorbed water in the $\mathrm{CH}_{4}$ hydrate phase or dissolved in the water phase. Another reason might be that the $\mathrm{CH}_{4}$ molecules encaged in the small cages are more stable (Ota et al, 2005b) than those in the large cages at low $\mathrm{CH}_{4}$ gas storage, hence the $\mathrm{CO}_{2}$ can replace the most of $\mathrm{CH}_{4}$ trapped in the large cages of methane hydrate and only a small part of $\mathrm{CH}_{4}$ in the small cages. The above two reasons may result in the difference between the $\mathrm{CH}_{4}$ amount from $\mathrm{CH}_{4}$ hydrate decomposition and the $\mathrm{CO}_{2}$ amount trapped in the hydrate phase.

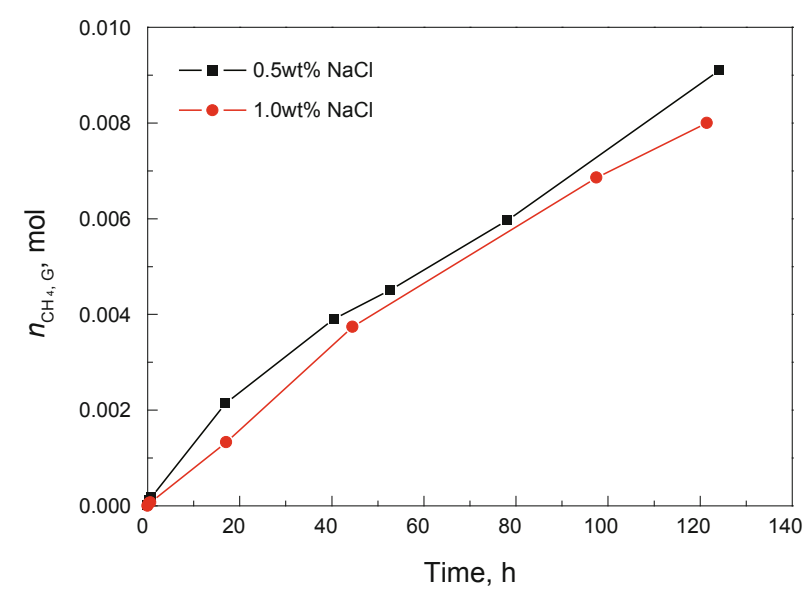

Fig. 4 Relationship of the $\mathrm{CH}_{4}$ amount $\left(n_{\mathrm{CH}_{4}, \mathrm{G}}\right)$ from $\mathrm{CH}_{4}$ hydrate decomposition with time at different $\mathrm{NaCl}$ concentrations at $275.05 \mathrm{~K}$ and $3.30 \mathrm{MPa}$

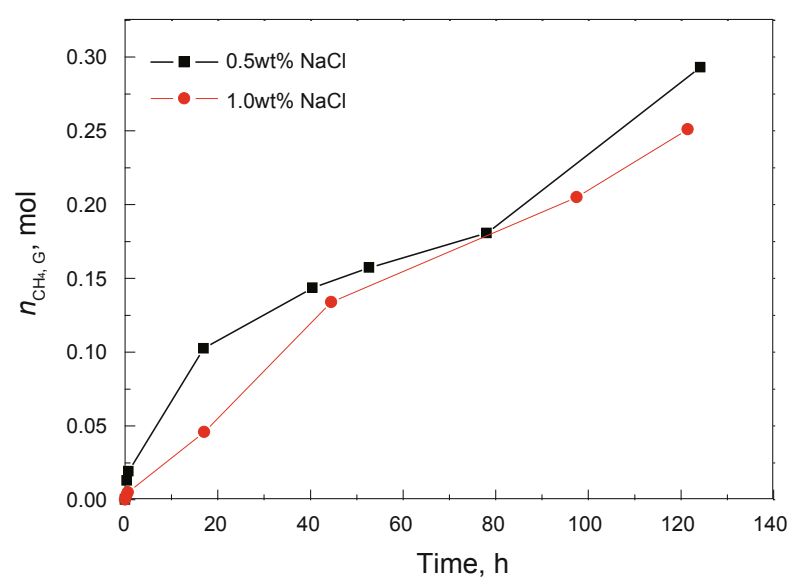

Fig. 5 Relationship of the $\mathrm{CO}_{2}$ amount $\left(n_{\mathrm{CH}_{2}, \mathrm{H}}\right)$ trapped in $\mathrm{CO}_{2}$ hydrate with time at different $\mathrm{NaCl}$ concentrations at $275.05 \mathrm{~K}$ and $3.30 \mathrm{MPa}$

\section{Development of kinetic model}

In order to further study the replacement process, the hydrate decomposition and formation models suggested by Bishnoi and Natarajan (1996) were applied to correlate the obtained experimental data. The models were also used for describing the $\mathrm{CH}_{4}$ replacement process in a pure water system by Ota et al (2005a). In this work, the driving force for the $\mathrm{CH}_{4}-\mathrm{CO}_{2}$ replacement process was assumed to be proportional to the fugacity difference between the gas phase and the hydrate phase. The model for $\mathrm{CH}_{4}$ hydrate decomposition is given as follows:

$$
\begin{aligned}
& \frac{\mathrm{d} n_{\mathrm{CH}_{4}, \mathrm{H}}}{\mathrm{d} t}=-k_{\mathrm{Dec}} A\left(f_{\mathrm{CH}_{4}, \mathrm{H}}-f_{\mathrm{CH}_{4}, \mathrm{G}}\right) \\
& \frac{1}{k_{\mathrm{Dec}}}=\frac{1}{k_{\mathrm{Dec}, \mathrm{R}}}+\frac{1}{k_{\mathrm{Dec}, \mathrm{D}}}
\end{aligned}
$$


Because the $\mathrm{CH}_{4}$ amount increased in the gas phase was equal to that of $\mathrm{CH}_{4}$ hydrate decomposition, Eq. 7 can be expressed as the following form:

$$
\frac{\mathrm{d} n_{\mathrm{CH}_{4}, \mathrm{H}}}{\mathrm{d} t}=-\frac{\mathrm{d} n_{\mathrm{CH}_{4}, \mathrm{G}}}{\mathrm{d} t}=-k_{\mathrm{Dec}} A\left(f_{\mathrm{CH}_{4}, \mathrm{H}}-f_{\mathrm{CH}_{4}, \mathrm{G}}\right)
$$

Where $t$ is the reaction time (s), $f$ is the fugacity (MPa), $k_{\text {Dec }}$ is the overall rate constant of the $\mathrm{CH}_{4}$ hydrate decomposition $\left(\mathrm{mol}^{-1} \mathrm{~m}^{-2} \mathrm{MPa}^{-1}\right), A$ is the surface areas $\left(\mathrm{m}^{2}\right)$ between the gas phase and the hydrate phase, which can be calculated from the diameter of the equilibrium cell. $k_{\mathrm{Dec}}$ consists of $k_{\mathrm{Dec}, \mathrm{R}}$ and $k_{\text {Dec, D }}$. The former $\left(k_{\text {Dec, R }}\right)$ is the rate constant of $\mathrm{CH}_{4}$ hydrate decomposition reaction and the latter $\left(k_{\mathrm{Dec}, \mathrm{D}}\right)$ is the rate constant of mass transfer of $\mathrm{CH}_{4}$ in the hydrate phase.

The model for $\mathrm{CO}_{2}$ hydrate formation during the replacement was similarly given by:

$$
\begin{aligned}
& \frac{\mathrm{d} n_{\mathrm{CO}_{2}, \mathrm{H}}}{\mathrm{d} t}=k_{\mathrm{Form}} A\left(f_{\mathrm{CO}_{2}, \mathrm{G}}-f_{\mathrm{CO}_{2}, \mathrm{H}}\right) \\
& \frac{1}{k_{\mathrm{Form}}}=\frac{1}{k_{\mathrm{Form}, \mathrm{D}}}+\frac{1}{k_{\mathrm{Form}, \mathrm{R}}}
\end{aligned}
$$

Where $k_{\text {Form }}$ is the overall rate constant of the $\mathrm{CO}_{2}$ hydrate formation $\left(\mathrm{mol} \cdot \mathrm{s}^{-1} \cdot \mathrm{m}^{-2} \cdot \mathrm{MPa}^{-1}\right)$, which also consists of two rate constants.

In these models, $f_{\mathrm{CH}_{4}, \mathrm{G}}$ and $f_{\mathrm{CO}_{2}, \mathrm{G}}$ are calculated with PT equation of state (Patel and Teja, 1982) for a certain elapsed time using the experimental temperature, pressure and gas composition of the gas phase. The fugacity in the hydrate phase $\left(f_{\mathrm{CH}_{4}, \mathrm{H}}\right.$ and $\left.f_{\mathrm{CO}_{2}, \mathrm{H}}\right)$ was calculated with the Chen-Guo hydrate model (Chen and Guo, 1998) using the experimental conditions. The $k_{\mathrm{Dec}}$ and $k_{\mathrm{Form}}$ were determined by minimizing the sum of squares of differences between the experimental values and those calculated from the proposed models. The calculated results and deviations are listed in Table 3.

Table 3 Calculation values of $k_{\mathrm{Dec}}$ and $k_{\mathrm{Form}}$ at different temperatures and $3.30 \mathrm{MPa}$

\begin{tabular}{ccc}
\hline$T, \mathrm{~K}$ & $k_{\mathrm{Dec}} \times 10^{5}, \mathrm{~mol} \cdot \mathrm{MPa}^{-1} \cdot \mathrm{m}^{-2} \cdot \mathrm{s}^{-1}$ & $k_{\text {Form }} \times 10^{5}, \mathrm{~mol} \cdot \mathrm{MPa}^{-1} \cdot \mathrm{m}^{-2} \cdot \mathrm{s}^{-1}$ \\
\hline 271.05 & $0.30 \pm 0.02$ & $4.50 \pm 0.41$ \\
273.15 & $0.35 \pm 0.03$ & $15.10 \pm 0.70$ \\
275.05 & $0.42 \pm 0.04$ & $32.86 \pm 2.91$ \\
\hline
\end{tabular}

Fig. 6 shows the relationship of $\ln k_{\mathrm{Dec}}$ and $\ln k_{\text {Form }}$ with temperature. The activation energies for $\mathrm{CH}_{4}$ hydrate decomposition and $\mathrm{CO}_{2}$ hydrate formation were calculated from the slope of the Arrhenius plot shown in Fig. 6. The measured activation energies for $\mathrm{CH}_{4}$ hydrate decomposition and $\mathrm{CO}_{2}$ hydrate formation were $52.01 \mathrm{~kJ} / \mathrm{mol}$ and $308.20 \mathrm{~kJ} /$ mol, respectively.

In this work, the activation energy of $\mathrm{CH}_{4}$ hydrate decomposition was calculated to be $52.01 \mathrm{~kJ} / \mathrm{mol}$. Ota et al (2005a ) investigated the kinetics of methane recovery from
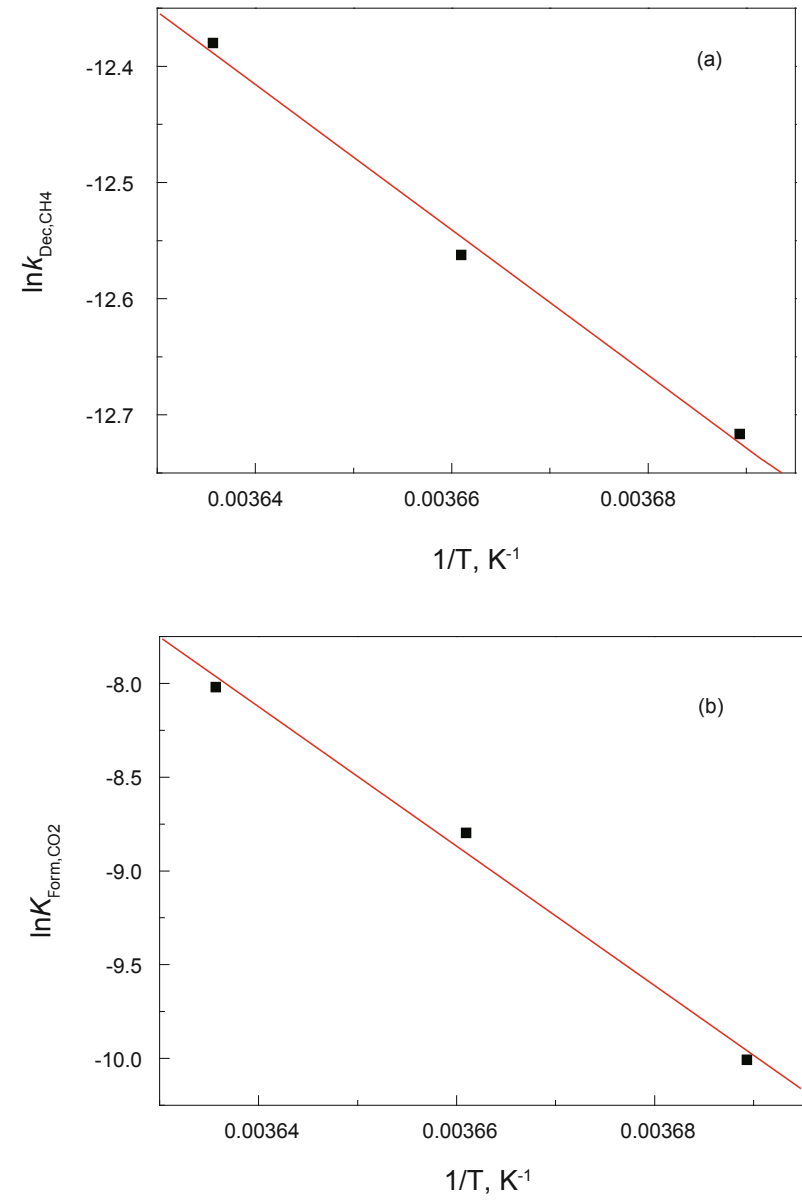

Fig. 6 Temperature dependence of the rate constants $\left(k_{\text {Dec }}\right.$ and $\left.k_{\text {Form }}\right)$ at $3.30 \mathrm{MPa}$

methane hydrate formed in pure water system by use of $\mathrm{CO}_{2}$ and obtained the activation energy for the $\mathrm{CH}_{4}$ hydrate decomposition as $14.5 \mathrm{~kJ} / \mathrm{mol}$. Li et al (2007) conducted the replacement process of methane from methane hydrate formed in sodium dodecyl sulfate (SDS) system and obtained an activation energy for the $\mathrm{CH}_{4}$ hydrate decomposition as $28.8 \mathrm{~kJ} / \mathrm{mol}$. The reason for great difference between the activation energies of $\mathrm{CH}_{4}$ hydrate decomposition reported by the above two group researchers and that obtained in this study might be that the mass transfer of $\mathrm{CH}_{4}$ gas in hydrate phase formed in $\mathrm{NaCl}$ system was more difficult than that in pure water system or SDS system. As mentioned above, the absorbed water existed in $\mathrm{CH}_{4}$ hydrate formed in $\mathrm{NaCl}$ system, making it difficult for $\mathrm{CO}_{2}$ diffusion in the hydrate phase. The activation energy for molecular diffusion in the solid phase has been reported often, for instance, the activation energy for $\mathrm{H}_{2} \mathrm{O}$ molecular diffusion in ice was $70 \mathrm{~kJ} / \mathrm{mol}$ (Livingston et al, 1997). In addition, Wang et al (2002) measured the kinetics of $\mathrm{CH}_{4}$ hydrate formation from neutron diffraction and reported that the activation energy for $\mathrm{CH}_{4}$ diffusion in the hydrate phase was $61.5 \mathrm{~kJ} / \mathrm{mol}$. From the above results, $k_{\text {Dec, D }}$ in Eq. 8 seem to be the controlling factor in the $\mathrm{CH}_{4}-\mathrm{CO}_{2}$ replacement process.

The activation energy for $\mathrm{CO}_{2}$ hydrate formation was determined to be $308.20 \mathrm{~kJ} / \mathrm{mol}$ in this work, which was 
larger than that for $\mathrm{CH}_{4}$ hydrate decomposition $(52.01 \mathrm{~kJ} /$ $\mathrm{mol})$. Ota et al (2005a ) obtained the activation energy for $\mathrm{CO}_{2}$ hydrate formation as $73.3 \mathrm{~kJ} / \mathrm{mol}$ and concluded that the $\mathrm{CO}_{2}$ diffusion in hydrate controlled the process of replacement. The activation energy for $\mathrm{CO}_{2}$ hydrate formation obtained in this study was very much larger than the value measured by Ota et al (2005a). We suggested that the $\mathrm{CO}_{2}$ hydrate formation may involve the following processes: As lots of absorbed water surrounded the $\mathrm{CH}_{4}$ hydrates, $\mathrm{CO}_{2}$ had to dissolve in the water phase and some $\mathrm{CO}_{2}$ contact with the $\mathrm{CH}_{4}$ hydrates to replace $\mathrm{CH}_{4}$ from $\mathrm{CH}_{4}$ hydrate. This process may need more reaction energy. So the diffusion for $\mathrm{CO}_{2}$ in hydrate $\left(k_{\text {From, }}\right)$ in Eq.11 seems to be the controlling factor in the replacement process.

\section{Conclusion}

The replacement of $\mathrm{CH}_{4}$ from $\mathrm{CH}_{4}$ hydrate formed in $\mathrm{NaCl}$ solution by using pressurized $\mathrm{CO}_{2}$ was investigated. It was found that the amount of $\mathrm{CH}_{4}$ released from $\mathrm{CH}_{4}$ hydrate and that of $\mathrm{CO}_{2}$ trapped in the hydrate increased with time. The higher the temperature, the more rapid the replacement reaction. The experimental data showed that $\mathrm{NaCl}$ has a negative effect on the replacement process. Kinetic models for $\mathrm{CH}_{4}$ hydrate decomposition and $\mathrm{CO}_{2}$ hydrate formation were developed by hypothesizing that the fugacity difference between the gas phase and the hydrate phase was the driving force for the $\mathrm{CH}_{4}-\mathrm{CO}_{2}$ replacement process. The experimental data and activation energies indicated that both $\mathrm{CH}_{4}$ hydrate decomposition and the $\mathrm{CO}_{2}$ hydrate formation were dominated by diffusion in the hydrate phase.

\section{Acknowledgements}

The financial support received from the National Natural Science Foundation of China (20476058, 20676146) and Ministry of Science and Technology of China (2006AA09A208, 2009CB219504) and Specialized Research Fund for the Doctoral Program of Higher Education (20070425001) are gratefully acknowledged.

\section{Nomenclatures}

$A \quad$ Surface area between gas phase and hydrate phase, $\mathrm{m}^{2}$

$f_{\mathrm{CH}_{4}, \mathrm{H}} \quad$ Fugacity of $\mathrm{CH}_{4}$ in hydrate phase, $\mathrm{MPa}$

$f_{\mathrm{CH}_{4}, \mathrm{G}} \quad$ Fugacity of $\mathrm{CH}_{4}$ in gas phase, $\mathrm{MPa}$

$f_{\mathrm{CO}_{2}, \mathrm{G}} \quad$ Fugacity of $\mathrm{CO}_{2}$ in gas phase, $\mathrm{MPa}$

$f_{\mathrm{CO}_{2}, \mathrm{H}} \quad$ Fugacity of $\mathrm{CO}_{2}$ in hydrate phase, $\mathrm{MPa}$

$k_{\text {Dec }} \quad$ Overall rate constant of the decomposition, $\mathrm{mol} \cdot \mathrm{s}^{-1} \cdot \mathrm{m}^{-2} \cdot \mathrm{MPa}^{-1}$

$k_{\text {Dec, D }} \quad$ Rate constant of mass transfer of $\mathrm{CH}_{4}$ in hydrate phase, $\mathrm{mol} \cdot \mathrm{s}^{-1} \cdot \mathrm{m}^{-2} \cdot \mathrm{MPa}^{-1}$

$k_{\text {Dec, R }} \quad$ Rate constant of decomposition reaction of $\mathrm{CH}_{4}$ in hydrate phase, $\mathrm{mol} \cdot \mathrm{s}^{-1} \cdot \mathrm{m}^{-2} \cdot \mathrm{MPa}^{-1}$

$k_{\text {Form }} \quad$ Overall rate constant of formation, $\mathrm{mol} \cdot \mathrm{s}^{-1} \cdot \mathrm{m}^{-2} \cdot \mathrm{MPa}^{-1}$

$k_{\mathrm{Form}, \mathrm{R}} \quad$ Rate constant of formation of $\mathrm{CO}_{2}$ in hydrate phase, $\mathrm{mol} \cdot \mathrm{s}^{-1} \cdot \mathrm{m}^{-2} \cdot \mathrm{MPa}^{-1}$
$n_{\mathrm{CH}_{4}, \mathrm{H}}^{i} \quad$ Initial amount of $\mathrm{CH}_{4}$ trapped in hydrate phase, mol

$n_{\mathrm{CO}_{2}, \mathrm{G}}^{i} \quad$ Initial amount of $\mathrm{CO}_{2}$ in gas phase, mol

$n_{\mathrm{CH}_{4}, \mathrm{H}} \quad$ Mole fraction of $\mathrm{CH}_{4}$ in gas phase

$n_{\mathrm{CH}_{2}} \% \quad$ Mole fraction of $\mathrm{CO}_{2}$ in gas phase

$n_{\mathrm{CO}_{2}} \%$ Total amount of $\mathrm{CH}_{4}$ and $\mathrm{CO}_{2}$ in gas phase, mol

T Temperature, $\mathrm{K}$

time Reaction time, hour

Superscripts

$i \quad$ Initial stage of the reaction

\section{Subscripts}

D Diffusion of molecule

Dec Decomposition reaction

Form Formation reaction

G Gas phase

$\mathrm{H} \quad$ Hydrate phase

R Reaction

\section{References}

Adisasmito S, Frank R J and Sloan E D. Hydrates of carbon-dioxide and methane mixtures. J. Chem. Eng. Data. 1991. 36(1): 68-71

Bishnoi P R and Natarajan V. Formation and decomposition of gas hydrates. Fluid Phase Equilib. 1996. 117: 168-177

Chen G G. and Guo T M. A new approach to gas hydrate modeling. Chem. Eng. J. 1998. 71: 145-151

Goel N. In situ methane hydrate dissociation with carbon dioxide sequestration: Current knowledge and issues. J. Pet. Sci. Eng. 2006. 51: $169-184$

Hao W F, Wang J Q and Fan S S, et al. Evaluation and analysis method for natural gas hydrate storage and transportation processes. Energy Conversion and Management. 2008. 49: 2546-2553

Hirohama S, Shimoyama Y and Wakabayashi A, et al. Conversion of $\mathrm{CH}_{4}$-hydrate to $\mathrm{CO}_{2}$-hydrate in liquid $\mathrm{CO}_{2}$. J. Chem. Eng. Jpn. 1996. 29(6): 1014-1020

Jadhawar P, Yang J H. and Jadhawar J, et al. Preliminary experimental investigation on replacing methane in hydrate structure with carbon dioxide in porous media. Proceedings of the Fifth International Conference on Gas Hydrates. Trondheim, Norway. June 12-16, 2005. (III): 1006-1011

Lee S Y and Holder G D. Methane hydrates potential as a future energy source. Fuel Process. Technol. 2001. 71: 181-186

Livingston F E., Whipple G C. and George S M. Diffusion of HDO into single-crystal $\mathrm{H}_{2}{ }^{16} \mathrm{O}$ ice multilayers: comparison with $\mathrm{H}_{2}{ }^{18} \mathrm{O}$. J. Phys. Chem. B. 1997. 101: 6127-6131

Li Z Z, Guo X Q and Wang J B, et al. Experiment and kinetic study on methane replacement from methane hydrate formed in SDS system using pressurized $\mathrm{CO}_{2}$. Chinese Journal of Chemical Engineering, 2007. 58(5): 1197-1203 (in Chinese)

Makogon Y F, Holditch S A and Makogon T Y. Natural gas-hydrates-A potential energy source for the 21 st Century. Journal of Petroleum Science and Engineering. 2007. 56: 14-31

Ohgaki K, Takano K and Sangawa H, et al. Methane exploitation by carbon dioxide from gas hydrates phase equilibria for $\mathrm{CO}_{2}-\mathrm{CH}_{4}$ mixed hydrates system. J. Chem. Eng. Jpn. 1996. 29(3): 478-483

Ota M, Abe Y and Watanabe M, et al. Methane recovery from methane 
hydrate using pressurized $\mathrm{CO}_{2}$. Fluid Phase Equilibria. 2005a. 228229: 553-559

Ota M, Morohashi $\mathrm{K}$ and Abe $\mathrm{Y}$, et al. Replacement of $\mathrm{CH}_{4}$ in the hydrate by use of liquid $\mathrm{CO}_{2}$. Energy Conversion. Management. 2005b. 46: 1680-1691

Patel N C and Teja A S. A new cubic equation of state for fluids and fluid mixtures. Chem. Eng. Sci. 1982. 37: 463-473

Seo Y T, Lee H and Yoon J H. Hydrate phase equilibria of the carbon dioxide, methane, and water system. J. Chem. Eng. Data. 2001. 46: 381-384
Sloan E D. Clathrate Hydrate of Natural Gases. Second Edition. New York: Marcel Dekker Inc. 1998: 538-585

Stern L A, Circone S and Kirby S H, et al. Anomalous preservation of pure methane hydrate at $1 \mathrm{~atm}$. J. Phys. Chem. B. 2001. 105: 17561762

Wang X, Schultz A J and Halpern Y. Kinetics of methane hydrate formation from polycrystalline deuterated ice. J. Phys. Chem. A. 2002. 106: 7304-7309

(Edited by Zhu Xiuqin) 